\title{
Roy F. Harrod and the Interwar Years ${ }^{1}$
}

\author{
E. Roy Weintraub
}

They are the saints living among us, these constructors of the historical record: William Barber on Irving Fisher, Donald Moggridge on John Maynard Keynes, Werner Stark on Jeremy Bentham, John Whitaker on Alfred Marshall, Donald Winch on James Mill. To this list we now need to add Daniele Besomi on Sir Roy Harrod.

In a review of Michael Bernstein's A Perilous Progress, Robert Nelson $(2003,376)$ notes that "Economists first clearly demonstrated their public importance by coming to Washington in large numbers in order to help in overseeing the vast output of armaments and other supplies that was the greatest U.S. contribution to the Allied victory in World War II. ... [so we can see the] golden age of economics as occurring from 1950 to 1970 . With the creation of the Council of Economic Advisors (CEA) in 1946, economists became the only professional body with a legal guarantee of access to the president's ear."

Economists became differently important in the post World War II era. The economists who defined that period, individuals in their middle adulthood, were students and young adults in the 1930s, and so they, with all the natural structuring of autobiographical memories (Weintraub 2005), recalled the 1930s to be the years of high theory, the most important period in the history of economics. Whether or not that makes historical sense today, the role that that decade has 
come to play in the collective imagination of modern historians of economics cannot be underestimated. We have a number of entry points as historians to those years. We have, of course, Keynes's Collected Works, including his correspondence. But when the Harrod family sold Roy Harrod's papers to libraries in Japan, to the great dismay of historians of economics, many believed that the archival collection of Keynes's first biographer would be lost to scholars for at least decades. That Daniele Besomi has made it his work to make the material available, and comprehensible, is one of the more remarkable stories of scholarship in our field. But publication of the interwar material is just one part of his larger project of cataloguing and locating all of Harrod's letters and papers. Nevertheless, with just these three volumes of Harrod's interwar correspondence and papers, we have a scholarly work of major importance.

There is a great deal to say about these volumes, the first two of which contain the correspondence and the third the interwar papers - essays and press items. A review essay can hardly do justice to the editor's magnificent success. The notes on the letters alone are worth the price of admission, and constitute a running exegesis of the emerging themes and issues, referring back to previous letters, and ahead to the continuation of the argument in subsequent letters. The "Forward" by Warren J. Samuels puts it well: "Besomi's collection is a major archival contribution to the history of economic thought of the interwar period." (xxix) He goes on to suggest that "Different readers will find their attention riveted to or whetted by different tidbits in these archival materials" as he goes on to highlight a large number of "tidbits" that engaged him. Let me do the same. 


\section{Getting Started: Harrod's Early Career}

Harrod met Keynes early on, as he was spending some time at Cambridge following his graduation from Oxford. 29 October 1922. "I take weekly essays in the ordinary way to Keynes. I have been enjoying myself here. I have read some but not much economics." A footnote states that Keynes's appointment diaries record five meetings with Harrod during the time he spent in Cambridge in October, November, and December $(15)^{2}$. Harrod certainly had strong early impressions of Keynes since a letter from Dundas to Harrod (14 September, 1923), in reply to Harrod's earlier letter, “...agrees with Harrod that Keynes' weakness is that he is not able to conceive of a friendship or attraction or sympathy which is not also erotic.” (22)

Harrod was elected lecturer in economics (2/3) and history (1/3) at Christ Church on 3 July 1923. "The economics teaching was on money and monetary theory" (37). The early letters recall that time in England in which one could receive a college appointment to teach a subject about which one knew virtually nothing. For example in correspondence with F. A. Lindeman (26 February 1926) Harrod remarks "you must remember that when I was appointed here [Oxford] I was, as was recognized, ungrounded in the subject of economics, and I have had to start from the beginning in making myself acquainted with what has been done in it. It is true that I have had three years to do so, but most of the while I have been in full blast teaching, and teaching, too, rather miscellaneous things. . I have found no one both able and willing to give me any guidance." (55) There is ample evidence then that Harrod had a lot of trouble beginning a career as an economist. We see that reflected in extended exchanges between Edgeworth and Harrod in 
1924, as well as in the many letters back and forth with D. H. Robertson and Irving Fisher from 1926.

The correspondence from 1927 shows Harrod beginning to get somewhat more comfortable in his career as an economist and this kind of material continues in 1928 with letters continuing between Harrod, Robertson, and Keynes. One of the more interesting bits here is a set of letters exchanged with Frank Ramsey in which, in response to queries by Harrod, Ramsey provides an analysis of a particular demand curve that leads to a particular mathematical formulation of a large firm selling in non-perfectly competitive market. This thus involves a price above marginal cost, and which algebraically is only a slight step away from marginal revenue, a concept which Harrod later believed he had developed, but had not specifically named.

It was not only that Harrod had difficulty beginning a life as an economist. His personal life was not going well. It was a struggle both in terms of money, for he had inherited nothing, and in terms of relationships, for his mother's mental-physical condition made a relationship impossible. As evidence of this we have some summer 1928 correspondence when Harrod apparently suffered a "nervous breakdown." Besomi brings forward material about that episode, and his lengthy footnote on page 102 goes into some of the family issues associated with Harrod's mother's "melancholia," which of course would now be termed depression. In a letter to J. D. Woodruff, (103) in December 1928, Harrod brooded that "while my mother lives I shall never do any good work on economics; I can't save money; I shan't marry. I found myself getting on better with my mother in some ways. . . but I find her more and more difficult with third parties." And this is followed by an excerpt from an autobiographical statement to his 
therapist, in the end of summer 1928, which notes "I became a don from necessity not choice. I shan't do any good on present regime. I shall find myself stranded in the middle 40s in a profession in which I am failure, un-married and with no money saved."

Nevertheless, by the end of the decade, Harrod seemed to be more able to make an impression professionally. He certainly found himself welcome in the larger world of arts and letters, as he was elected to the Cranium Club in April 1929 (126), a group whose members included Bertrand Russell, Whitney Oliver Strachey, Duncan Grant, E. Sackville-West, and Leonard Woolf. Nevertheless, his connections with economists were mostly though letters: on 4 January 1931 Harrod wrote to Keynes thanking him for their talk, remarking "I've no one with whom I ever discuss economics in [Oxford] apart from pupils. Even Robbins has gone.” (125)

A lengthy letter from Frank Ramsey, dated 16 September 1929 (110-112) concerns what we now call the marginal revenue curve. Ramsey's mathematics develops an argument about the relationship of marginal cost to price with price being multiplied by an expression that includes the elasticity of demand. This of course is marginal revenue. It is simply not named as such in that exchange with Harrod, although it was to form the substance of Harrod's claim that he was the creator of marginal revenue even though he did not name it, and thus was not given credit for it. This is confirmed by some letters from the summer of 1931 to and from Joan Robinson dealing with the question of marginal revenue and marginal prime cost and the fact that they were working on very similar lines. 
This issue remained "live" in the next few years. In a letter to Joan Robinson on 1 July 1933 (222) Harrod writes "as a matter of history it might interest you to know that I devised and wrote an article about the [marginal revenue] curve which I sent to the [Economic] Journal in the summer of 1928. Unfortunately the article contained some other matter with which Maynard didn't agree and he handed it over to Ramsey to refute. I became ill about that time and didn't bother about it for a year or so. When I looked it up again, I wrote to Ramsey replying to his refutation, and he replied in a letter, which I have got, entirely surrendering and indeed providing a rather elaborate mathematical demonstration of my points - these were points other than those connected with the MR curve. Meanwhile I became dissatisfied with the article on other grounds and did not press for its publication. I scrapped it; and in 1930 wrote a quite different article but embodied in it my original construction of the MR curve." In this letter what we have clearly is Harrod asserting his own priority in discovery of marginal revenue. Nevertheless, he quite acknowledges Joan Robinson's use of marginal revenue, and her actual publication of it in that form in her book, The Economics of Imperfect Competition. This point in fact was acknowledged by Robinson in her reply of 10 July that "I am delighted to hear that the first discovery of [marginal revenue] was yours and not Yntema's. His grubby article was a very poor cradle for it. Of course at L.S.E. they say it's all in Cournot!” (223)

This is also a period of time, in mid 1932, that Harrod gets involved in getting a letter published in the Times, with a number of other signatories. The letter urged re-inflation, which is essentially a Keynesian policy, to recover from Churchill's disastrous return to the gold standard. Such a public expression was not a singular event for Harrod. One of the fascinating points that emerges from Harrod's letter writing activity is that as a rather junior Oxford don he sent a letter, 
with a number of other signatories from Oxford, to Franklin Delano Roosevelt through Felix Frankfurter. The letter (236-241) concerns economic policy in a depression and begins

"We feel strongly that this problem [the depression] is not to be solved by the method of waiting for it to solve itself. We believe that a deliberate policy of expansion is desirable, both to hasten the amelioration of present troubles and also to lay the foundations of policy designed to prevent the recurrence of similar troubles in future...We therefore welcome with enthusiasm the indications which came to us that an expansionist policy was likely to be pursued and that a program of public works was to play a prominent part in it." (236)

What we have is Harrod, and the other Oxford signatories, none of them part of the Cambridge Circus, urging Keynesian policies prior to the theorization of those policies in a full-blown fashion in Keynes' just-being-created General Theory of Employment, Interest and Money. This provides more evidence for the now standard view that there was a large literature advocating public works in the mid-1920s to mid-1930s, a literature that used arguments quite different from the ones Keynes put forth in his 1936 book (e.g. Hutchison 1968; Davis 1971; Howson and Winch 1977). We now understand that the solution to the depression was not simply Keynes', nor was it a result of Keynes' theory, but rather that Keynes' theory emerged as the unifying glue to what had been emerging as a policy consensus. Indeed, January 1934 opens with a letter (262-263) to Harrod from Felix Frankfurter stating that the President "read the memorandum of 
your Oxford friends to a small group of my advisors and the consensus of opinion was that the Oxford economists are in general thinking along the same lines as we are." This message from Roosevelt to the still "junior" Harrod and the Oxford economists via Frankfurter is quite startling.

And of course, besides writing to American Presidents and Supreme Court justices, Harrod was carrying on a lively correspondence with A. J. Ayer on questions of sense data, and the foundations of epistemology.

\section{Becoming a Keynesian}

The year 1933 shows Harrod's continuing correspondence with Keynes, Runciman, Joan Robinson, Meade, Kahn, Robertson, etc. It's interesting to note that Harrod is now "Dear Joan"ing to Joan Robinson. Some correspondence with Robertson in Spring 1933 suggests that neither Harrod nor Robertson, not just Robertson alone, were “on board” with Keynes' evolving General Theory (219). They jointly raise questions about terminology and the nature of savings and investment, and Harrod simply is uninterested in following Keynes's saving-investment definitions in the Treatise on Money. Nevertheless, the letter of Harrod to Robertson on 29 April 1933 suggests "I was not going farther than trying to ease the pain caused by our failure to decide what the doctrine of the Treatise in its crude form implied." Harrod in other words was continuing to try to work out the nature, meaning, and implications of Keynes' Treatise on Money. That the Treatise was evolving, and by 1933 April almost certainly had evolved, to the central new message of The General Theory, was not something Harrod apparently understood. 
For it appears that it wasn't until late October 1933 that Keynes gets around to letting Harrod know that Harrod's attempts to understand the Treatise had been mooted by his, Keynes', new work:

\footnotetext{
"The view you [Harrod] are taking is the usual argument, and my criticism is prompted by a lot of stuff I am now doing as to the inapplicability of many of the classical assumptions to a monetary entrepreneur economy. Even if I am right, I cannot expect you to agree until you have read some 100 pages or more of unpublished material.” (229)
}

Later in 1934, in summer and early fall, there is some correspondence between Harrod and Gottfried Haberler, mostly concerning Hayek and his views on the trade cycle. In a similar fashion, there is further correspondence with D. H. Robertson, who notes to Harrod "It appears to me that your new scheme resembles Maynard's Treatise one (now, I gather, abandoned) in that, setting out to be the analysis of causes, it ends up by being a repetition of results. (298)" This suggests to me at least that Robertson not only was out of the loop with respect to Keynes and his ideas as they were evolving, but that Robertson still felt close enough to Harrod to believe that Harrod was, like him, interested in arguing about questions raised by Keynes' Treatise on Money. 
As a window into the mid 1930s, these letters are sublime. For instance, in a letter of R. F. Kahn to Harrod of 22 October 1934 we find Kahn saying:

"How prices behave depend on how wages behave, and that in turn depends on how Trade Unions behave. If at a time of increasing efficiency it is desired to keep prices stable it is necessary to give such stimulus to the demand for labour that wages go on rising in exactly the rate in which efficiency is increasing. Whether that is desirable or not depends entirely on how responsive money wages are. If Trade Unions respond readily to prosperity by demanding and securing higher wages, then the policy might be desirable, or it might actually be desirable to have rising prices. ... In short, I do not think in terms of money and prices. In the view of Keynes and his followers the Theory of Money has ceased to exist. Of course that is an exaggeration (it is the quantity of money which determines the rate of interest), but the exaggeration is a pardonable one." (308-309)

We see here, in this letter of Kahn's 1934, the entire Post Keynesian foundationalist position on inflation. It's the Trade Unions' fault or, rather, prices depend on the relation of the rate of increase of wages to the rate of increase in average productivity, what Kahn calls "efficiency". This notion that wages are exogenous to the system, a matter of bargaining between employers and workers represented by Trade Unions, was to shape a great deal of the cost push versus 
demand pull division in the 1959-1969 period, which produced the split between the American Post Keynesians, and the American Keynesians, the latter whom Joan Robinson called Bastard Keynesians.

In response to Kahn, in 29 October 1934 Harrod notes

"I agree that the responsiveness of money wages is a fundamental element in the problem. You say that there is no sense in which I is greater than S. . . but of course it is in JMK sense. Whatever are the faults in his equation, that main proposition is sound on his definition. Is now the old terminology now to be scrapped? This makes a severe demand on the general public. If the Treatise is to be put in cold storage for a year, what are we to teach? We have not only to consider the truth, but education which is done through standard terms and concepts. If the language is perpetually to be altered, progress is hardly possible. Language is one thing and truth another." (320-321)

Here we have one of the problems faced by those who were sympathetic to Keynes in the mid 1930s: they had invested heavily in mastering the comprehensive framework of the two volume Treatise on Money and now Keynes had changed his mind again! Even more interestingly, he had changed all the definitions and terminology back again to what they were before he had redefined the concepts in the Treatise. 
Of course Harrod's role in the "Keynesian Revolution" as it was to be called features prominently in the correspondence. On 13 November 1934 R. F. Kahn writes to Harrod on Keynes' emerging theory, and the role that he Kahn expects Harrod to play in its promulgation:

"I do hope that we shall gradually find ourselves able to see eye to eye on these questions. You are one of the few economists in the whole world on whom Maynard can reckon. I do not add the words "outside Cambridge" because the number of Cambridge economists, as [you] may by now have noticed, who can readily be regarded as Maynard's supporters is a vanishingly small quantity. Such as we are, we do very much look to you as a leader in what must after all be described as a fight. If I have said anything to annoy you, please put it down to the thoughtlessness which the heat of battle always engenders in me, far more against those on whose side I am myself fighting than against the common enemy.” $(341-342)$

It was Harry Johnson who described the Keynesian revolution in missionary terms, as zealotry involving conversion experiences, in which a loyal band took the master's message outward from Jerusalem: here we see Kahn begging Harrod to sign up for the mission. It certainly was seen as an imperative by Keynes's Cambridge acolytes to convert, or more mildly convince, economists that Maynard was right. 
Harrod's reply to Kahn dated 17 November 1934 resists that plea somewhat, and takes up a number of specific issues, including questions of the nature and relation of equilibrium ideas to Keynes' emerging views. Wanting to be quite comfortable in the new faith, he says:

"I want your and Maynard's economics of full employment expressed in terms which are used in marginal analysis, so that it can be fitted into the corpus of economic theory such as it is. I think that the equilibrium economists wrongly believe that they have demonstrated that the system tends to move, apart from rigidities, to a full employment position, and that you can only disabuse them of this and impel them to take up your doctrines if they are expressed in the same language as theirs." (345-346)

What we have here is Harrod demanding that there be a neoclassical synthesis! Harrod is calling for a micro foundations of Keynesian macro economics in 1934, two years before The General Ttheory even appears in print, as a way of selling Keynes' idea to economists. Harrod is arguing that without a coherent microfoundations perspective on equilibrium, Keynesian economics will simply be "other", and will not be able to be accommodated to the intellectual world view that economists share. More to the point, Harrod is arguing that Keynes' General Theory can indeed be so presented. These eventually were the fault lines that were to emerge in the 1940s and 1950s, and which were ultimately to produce elements of the counterrevolution against Keynesian ideas in the 1970s and 1980s. 
On 26 June 1935 (395) Keynes sends Harrod, his Oxford representative as it were, the galley proofs for The General Theory (with the exception of the three concluding chapters). This generates a sequence of letters between Harrod and Keynes, seen earlier in Keynes' collected correspondence, on the writing of the final draft of The General Theory. Harrod's "position" is clear: On 6 August 1935 he writes "I feel that the only way I could possibly be of any assistance [now] is not in the elaboration of your own view, but in endeavoring to restrain you in your criticism. I feel that you have been thinking so much about your own views that you are inclined to do less than justice to the existing doctrines" (408). Keynes' famous reply notes:

"If I had left out all the parts you object to about the classical school, you would have simply told me that you are largely in sympathy and liked it. But my attack on the classical school has brought to head the fact that I have only half shifted you away from it. Your preoccupation with the old beliefs — and much more so in the case of most other people-would prevent you from seeing the half of what I am saying unless I moved to the attack." $(422-426)$

Here in fact we have the fullest expression of Keynes' method of selling the general theory itself, rhetorically of course. 
The selling had some unpleasant side effects, among them the marginalization of D. H. Robertson by Keynes's zealous crusaders. In a letter to Harrod on November 1935, Robertson responds to Harrod's earlier note in which he proposed writing an intellectual history of Keynes' General Theory, tracing out various lines of thought which converged to produce that 1936 volume. To this plan, Robertson replied:

"I am most anxious that in your dogmengeschichte_when it appears you should not over stress JMK's obligations to me. He has always been most generous in his acknowledgements (see preface to Treatise): \& I in return avow that a good deal of the central point of [Banking Policy and the Price Level] was hisincluding the 'induced lacking' which was the germ of what seems to me sound in his later developments. It is the most painful part of this whole position that my attempts to show that the new doctrines are largely a re-statement of old truths are apt to seem like assertions of my own priority. . . But the real point is not a personal one to me, -- it is the spiritual necessity which JMK seems to be under to disparage all previous work in these fields and to resent any attempt to show the affinity between some of his concepts and conclusions and those of previous writers, --it is a greater crime to reach agreement with him by other lines of thought than to differ from him! So please go carefully, and in such wise as not to make a difficult situation worse!" (458-460) 
This difficult situation of course was to induce Robertson to leave Cambridge, and eventually, on his return, to spend his time being hectored by Joan Robinson and Richard Kahn and their acolytes. Of this construction of the world of (especially British) economics into friends and enemies of The General Theory, we have the remarkable account by Harry Johnson on Cambridge in the 1950s in his book (1978) with Elizabeth Johnson, The Shadow of Keynes. This of course is echoed on numerous occasions, for example in a letter Lionel Robbins sent to Harrod on 13 February 1937:

"Firstly I think it is a little misleading to refer to the existing of a [anti-Keynesian LSE] 'school' in this connection [response to Keynes' General Theory] ... Whatever you may think of Hicks, Lerner, Douglas Allen, Kaldor, Durbin, Bird, Coase and many others, you certainly must agree that they are not particularly tainted with any orthodoxy other than that ... of not thinking that economics began somewhere round 1930!" (623)

This division of economists into Cambridge and non-Cambridge, into those who had as it were been saved by accepting Keynes's gospel, versus the great unwashed who had not, has had some pernicious implications for the history of economics. It has led to the enormous literature on the development of The General Theory, and the associated importance of Cambridge economics. To some extent this is a product of the longer association of British trained economists with work in the history of economics: today not many economists in the United States are educated in the 
history of the discipline, and consequently the concerns of those who are not Cambridgeconnected are usually not associated with Cambridge traditions. In modern times the large biographies by Gronewegen of Marshall, and by Moggridge and by Skidelsky of Keynes, are testament to this connection. In terms of actually doing economics, as opposed to criticizing mainstream economics, there is not much activity separating mainstream Cambridge from the rest of the world. Nevertheless there is much use made of the "Cambridge tradition", even today.

For instance, the Cambridge Realist group associated with Tony Lawson makes much of the continuity of a grand tradition in Cambridge that begins with Marshall, moves through Keynes, Joan Robinson, Nicky Kaldor, and Geoff Harcourt, and leads up to Lawson. Nevertheless in Harrod's letters we find a much more complex tale unfolding, perhaps because the nonCambridge Harrod sees those Cambridge matters differently. Specifically, the idea that there was a monolithic Cambridge tradition is historical nonsense: Henderson, Robertson, Shove and Pigou of course were just as Cambridge, just as legitimately heirs to Marshall's creation, as were Keynes, Robinson, and Kahn. For instance, in a letter of 24 February 1936 from Harrod to Hubert Henderson at Cambridge, Harrod writes:

"When I find someone like you supposing that there really is enshrined in Marshall a theory about the way things work themselves out in the long period, that will wash, that will do, that really works and hold together, then I feel that Maynard is amply justified [in attacking Marshall in The General Theory]. I begin to understand why he fusses so much about Marshall. He lives in 
Cambridge and probably comes in touch with other people like

yourself who take him au grand serieux. Nothing is more

dangerous than to lull oneself into believing that one has stored up

somewhere in the less-used brain-cells a theory that does explain the main working of the system when that is not the case. If we are

naked, let us know it. Far be it for me to disparage Marshall. I

have the highest regard for him. But do not let us suppose that he

has provided a coherent theory of the long period working of

economic forces that is in any sense complete." (515)

\section{The “Cambridge Tradition” on Mathematics and Economics}

One of the themes articulated in this supposed Cambridge tradition concerns its appropriate Marshall-influenced resistance to mathematical argumentation in economics. I submit however that this is not entirely correct, since the Marshallian anti-mathematics perspective was not necessarily even the majority view among the relevant British economists. Consider the letter from Phelps-Brown to Harrod on 1 August 1931 suggesting, following his meeting and work with Henry Schultz, that "economists at Oxford should break the traditional association with historians and philosophers, and should align instead with the natural scientists" (136) He maintains that a proper "school should be founded, and that the mathematical and statistical literature should be made easily available, as well as calculating machines." Certainly there was "anti-mathematical" rhetoric among those who associate themselves with Cambridge economics, 
but is difficult to pin down its actual shape and details. For instance, consider Henderson's reply to Harrod of 23 February 1936:

"I took you to be justifying the pursuit of your method by an appeal to Marshall's 'authority,' and I merely sought to demur that he appreciated the mathematical stuff was only a toy by relegating most of it in later editions to an Appendix. But I certainly agree with you that many parts of Marshall's theory that you mentioned are very unsatisfactory. I only differ in the moral I draw, that Marshall carried abstract semi-mathematical analysis further than it would profitably go where as your school carries still further into (as it seems to me) aridities. This isn't a distaste for exact reasoning, but a different conception of the sort of reasoning that is appropriate to different problems." (516-518)

What we have of course is that Harrod, a Keynesian, and a non-mathematical one at that, is being castigated by Henderson for being too mathematical. Something is very strange here.

That Henderson is berating Harrod for being too mathematical is ironic in the view of the letter that he writes to Harrod in this sequence (536-541) on 2 April 1936 which ends "I regard Maynard's book, as I say in my paper, as a farrago of confused sophistication, and I find intensely exasperating the tacit assumption that prevails in certain circles that those who do not accept its general doctrine are to be regarded as intellectually inferior beings." In response to 
that last from Henderson, Harrod had, as we say in the American South, a conniption fit, shared in a letter dated 9 April 1936:

"I thought it wonderfully clear and lucid and coherent and consistent. I cannot believe that my mental faculties were so blunted as to not notice the farrago of confusion. I had absolutely no ax to grind. I owe nothing of material importance in life to Maynard! Nor do I have any expectation of benefit! He taught me for a term in Cambridge, has always been very kind about little things and is a constant source of intellectual illumination. But I cannot believe my judgment had been so warped. You say that in certain circles those who do not accept this doctrine are regarded as intellectually inferior beings. That would of course would be absurd and intolerable. But is it really so? I cannot think what those circles are. Perhaps two people in Cambridge together with a few undergraduates. No; I don't think we need worry about that." (544)

The issue of the use of mathematics in economics of course is a particular concern of mine, and so I have an historian's interest in the putative Cambridge "position" on this matter. In this vein I was fascinated by an exchange involving Harrod, G. D. A. MacDougall, and Keynes on 2 July 1936. In it Keynes passes along a paper by MacDougall, a preliminary version of his "The Definition of Prime and Supplementary Costs." Keynes notes 
"I am not perfectly convinced that he is really an economist rather than some kind of mathematician or logician. I have had the same kind of doubt as I have had about a good deal of Champernowne's work. I feel increasingly that one cannot think as an economist unless one's method of thought is capable of handling material which is not completely clear-cut and which is, so to speak, symptomatic thinking ... rather than completely formal, watertight thinking. What one hopes from people like Champernowne and MacDougall is that they may learn to be mathematicians and economists simultaneously, capable of keeping in their minds at the same time formal thinking and shifting uncertain material."

Additional material from Keynes's letter to MacDougall, a bit different from Keynes' comments on MacDougall in the letter to Harrod, continues this argument:

"If the completely formal treatment could be maintained to the bitter end, then it will be well worthwhile. But in economics it is the very nature of the case that in a fairly early stage in the argument it has to be discarded. As a rule it is impossible to pursue an economic argument to a point where it is useful whilst maintaining so high a standard of formalism as you have set 
yourself. Thus, just when one reaches the stage where formalism might save one from mistakes it becomes necessary to throw it away. . I have an aversion to superfluous formalism in economics unless it is quite clear that it is required for the accurate statement of the ideas involved." (566 note 3 )

One hears the echo in this letter of Marshall's 1906 letter to Bowley, about the need to "burn the mathematics". That Keynes, writing a quarter century after Marshall, speaks of exactly the same relation of economics and mathematics, is significant, but not for the reason that is commonly maintained. That is, it is less important that Keynes's views here are consistent with Marshall's, than it is to recognize that Keynes understood mathematics to function exactly as had Marshall. For Keynes, mathematics and economics were the same in 1936 as they were in 1906, which means that he seems to have no historical understanding of the changes that had been occurring, in a dramatic fashion, in mathematics. Keynes' own mathematics was mired in his own turn of the century undergraduate experiences, which appeared to reflect Marshall's own experiences of the mid $19^{\text {th }}$ century Mathematical Tripos. It is curious that Cambridge-connected histories of economics critical of "formalism", done by individuals interested in the connection between history and economics (cf. Lawson 2004) show so little understanding of the history of the mathematical ideas they are criticizing, like "formalism" itself. Keynes' letter to Harrod of 30 August 1936 unwittingly confirms this:

"What some people treat as an unnecessarily controversial tone is really due to the importance in my own mind of what I used to 
believe, and of the moments of transition which were for me personal moments of illumination. You don't feel the weight of the past I do. One cannot shake off a pack one has never properly worn. And probably you are ignoring all this is a better plan than mine." (580-581)

What is telling here is that Keynes' views on unemployment are associated with this kind of change, but not his views on the relations between mathematics and economics. He is, of course, as much a prisoner of the past in the one as in the other, though he only attempted to escape the past in his economics.

That there was in fact no coherent Cambridge-Keynes position on mathematics in economics is made clear in the remarkable letter that Harrod sent to D. H. Robertson, dated 3 October 1935. After raising some questions about a paper of Robertson's, Harrod notes:

"I have before me Econometrica, with its Tinbergen and Kalecki. I suspect that Kalecki is saying something that I have been feeling towards, and I have got to try and find out. But what a paper it is! I also suspect that economics will sink deeper and deeper into some sort of scholastic morass until we all become Wesley Mitchells. And that is rather gloomy. I just can't become a Wesley Mitchell, so what am I to do? My only ray of sunshine is Maynard's book. I think I agree with him (as against you?) that his 
book, if true, is path-breaking. I hold that a strong committee of economists ought at once to be formed to decide whether or not it is true, or, at least, to draw up an agreed list of propositions embodying in their own language what the book is contending. Only if that is done as preliminary will there be any possibility of assessing it." (440-441)

We see here how Harrod takes Keynes as an alternative to quantification, or at least quantification in the sense of Tinbergen and Kalecki, the former econometric, the latter mathematical. Wesley Clair Mitchell of course was a data-based economist, to some degree institutionalist but at least anti-theoretical, as his careful inductivism and statistical analysis of phenomena provides an alternative way of doing economics. But Harrod was a prisoner of his own training, and since he didn't want to become a Mitchell, and couldn't become either a Timbergen or Kalecki, he believed he had to become a Keynesian. One of the startling implications of this is that a strong motivation for the adoption of Keynesian ideas by a number of British economists was associated with the fact that The General Theory placed no mathematical or econometric demands on the reader. This of course was not to be true for a later generation, especially as Samuelson, and his student Klein, moved the Keynesian message into mathematical and econometric areas. But the inadequate mathematical education of British economists certainly goes some degree, some distance, in providing an explanatory framework for the rapid adoption among them of Keynes' theory in contrast say to the lack of adoption of Tinbergen's ideas. 


\section{Harrod's Dynamic Theory}

Given my own family history, the letter from James Meade to Harrod of 12 January 1936 was startling. In it, Meade writes a note on some material that Harrod was going to lecture on, and which he had asked Meade to discuss. Meade's mathematical analysis of a model involving capital, investment, and labor growth sets out (as equation $\mathrm{v}, 482-488)$ the equation $(1 / \mathrm{w} \cdot \mathrm{dw} / \mathrm{dt})$ $(1 / \mathrm{p} \cdot \mathrm{dp} / \mathrm{dt})=(1 / \partial \mathrm{x} / \partial \mathrm{l}) \cdot \mathrm{d}(\partial \mathrm{x} / \partial \mathrm{l}) / \mathrm{dt}$. What this is of course is that the percentage rate of change of wages minus the percentage rate of change of prices, or wage inflation minus price inflation, equals the percentage rate of change of the marginal product of labor. Put another way, prices grow at the difference between the rate of wage growth and the rate of productivity growth. When my father "discovered" this relationship in the late 1950 s, roughly 20 years later, he called it the "wage cost markup identity" (Weintraub 1959). Meade simply identified it as equation (v).

This lengthy correspondence with Meade, effectively looking at the relationship between wages and prices over the business cycle, based on Keynes' work, takes up a good bit of the early pages of volume two. It leads naturally into Harrod's next round of correspondence with Keynes, as he begins to take up the issue of making the Keynes's theory dynamic, extending its analytical framework to the discussion of the trade cycle itself. In this vein we have the letter from Keynes to Harrod of February 1936 saying "I am very glad to hear that you are turning your mind in a constructive direction, and I'm very much in favour of your doing something on the trade cycle. My stuff is deliberately in the nature of prolegomena; and except where people differ fundamentally that is how I hope it will be used" (507). 
Besomi himself has told the story of the creation of Harrod's dynamic theory before (Besomi 1999), and in that fine book used a number of the letters we find here. Nevertheless it is still is an interesting story that unfolds, one in which Harrod's ideas are initially thought to be quite wrong, then are thought to be quite difficult to interpret, then are quite ignored as a new generation of theorists rewrite economic dynamics from a mathematical perspective. Since the last part of that story extends beyond the interwar period, it is not part of these volumes. Nevertheless the stabilization of the theory of economic dynamics (Weintraub 1991) was certainly foreshadowed by the arguments that earlier swirled around the development and presentation of Harrod's theory.

Keynes' first comment on Harrod's book on the trade cycle appears in a letter dated 31 March 1937, in which he says

"You will see ...that, while I have learned a great deal from the book and have had some important ideas put into my head, I think that your theory and the form in which you finally enunciate it is not correct, being fatally affected by a logical slip in the argument. Unless I have quite misunderstood you, the slip is an obvious one" (646).

This initial reaction was upsetting to Harrod, who spent a week examining the notes Keynes had provided to support his first response. He wrote back on 6 April 1937 pointing out "The fact is 
that you and your criticism are still thinking of once over changes and that is what I regard as a static problem. My technique relates to steady growth" (660-662).

Keynes apparently thought through the matters again, and on 12 April 1937 told Harrod:

"I have undoubtedly misunderstood you and there is no question of an arithmetical slip. But the odd thing is that, having invented so interesting a theory, you should not have mentioned it in the book! For I do not see how I could have possibly have understood what you're driving at in the passage where I accuse you of an arithmetical slip. Indeed, I should doubt whether any reader who has not talked or corresponded with you could be aware that the whole of the last half of the book was intended to be in relation to a moving base of steady progress. Moreover, it is not as though your theory was a simple one which only had to be mentioned in a sentence. It seems to me to involve important and difficult considerations about the relation of the rate of progress with the Multiplier and the Relation. Finally, you put your readers off the track by calling your book "The Trade Cycle," and arguing as though your thesis principally related to that. For it seems to me that your theory has little or no bearing on the trade cycle, though none the less interesting for that." (670-672) 
The problem here is that Keynes, not really understanding what Harrod was about, was prefiguring the general response to Harrod's dynamic theory. Very few people "got it." Harrod then was to spend long periods of his professional career defending his position, a result of the fact that it was worked out nonmathematically. The tension between Harrod's nascent realization that he had to work out his theory in mathematical terms for it to be comprehensible in its structure and details, and his inability to work in that fashion, is in the end tragic. His intellectual legacy is small, but it could have been otherwise had he not worked in the soon to be no-longer-mainstream Cambridge fashion. Keynes nevertheless tried to bolster Harrod's selfesteem, writing on 6 June 1937: "What a miserable (and frequently dishonest) review of you is H's [Hansen's] in QJE but don't reply. Since every one of your major points has escaped him, there's really nothing to reply to!" (696)

Harrod was aware of the difficulty he faced in selling his ideas for the economics community was changing, and economists were reading Econometrica and the Review of Economic Studies, and not just the Economic Journal. Consider the important letter, dated 1 July 1937, from Harrod to Tinbergen, occasioned by the Dutchman's review of Harrod's book:

"I fear that my mathematics are rather rudimentary and that any single-handed attempt to give a rigid mathematical formulation to my theory would not be successful. But I am contemplating a quasi-mathematical article elaborating my central thesis. I am aware that my fundamental propositions do not yield a sine curve of the kind that your soul delights in. I do not think it follows that 
they necessarily fail to demonstrate the inevitability of the cycle.

On the look out for a certain type of equation you have, I think, done less than justice to my argument at this point.” (705-707)

Harrod then goes on to draw a few curves. This is entirely inadequate though to the kinds of remarks that Tinbergen was developing. This exchange is developed by Besomi in a lengthy footnote, having been further explored in productive detail in an earlier paper by Albert Jolink (1995, 441-442). It was in this period of Harrod's mixed professional success that we find letters to and from Wilhelmine ("Billa") Cresswell as their relationship was developing, and which would lead eventually to their marriage on 8 January 1938.

\section{Methodological Issues}

One of the more illuminating "perspective" letters in the entire collection was from Harrod to Keynes on 6 July 1938 and the follow-up letter from Keynes on 10 July. This was associated with Harrod's Presidential Address to the British Association (Section F), "Scope and Method of Economics". It is worth quoting in detail. Harrod writes:

"I'm not sure that I agree altogether with your hostility to the idea of economics as a natural science. . . With regard to Schultz, I intended to indicate that his particular work is probably more or less a waste of time. But this is only to the extent that one admits 
that the theory of value as set out by Marshall, Walras, Cassel, etc. is played out. This still occupies the central position in any textbook of economics. If on the other hand these equations of static theory are of importance, surely they should be given provisional quantitative significance, even if this had to be re-done from time to time. Just as, surely, one wants to know the value of the Multiplier, even if one also knows that it is subject to both cyclical and secular change... While, therefore, I agree more or less about Schultz, I feel that Tinbergen may be doing very valuable work, in trying to reduce this part of theory to quantitative terms. ... but I begin to feel that the time has come when I ought to soil my figures by doing some of this sort of statistical work myself or supervise others in the doing of it. I make a statement about the "acceleration principle." Then Tinbergen comes and says that the facts do not suggest that it has had the influence I ascribe to it. Surely one ought not to leave the matter there. To Tinbergen the statistics merely suggested a negative result; to me, if I applied his technique, they might suggest a refinement of my concepts or re-stressing of the importance of one at the expense of the other. I confess all this frightens me a little. I imagine the possibility of a vast amount of time-wasting. But I have a feeling that one ought to take the risk. The trouble with the statisticians I feel is that they are too divorced from theory to derive the full 
benefit of their own experiments with figures. We have a sort of minor Tinbergen here in the form of Marschak. It is awfully funny to watch Hubert Henderson's reaction to his statistical findings. He thinks the whole thing obvious nonsense.... If there is to be a developing subject with a lot of workers, competent but not outstandingly expired, who want to find systematic work to do, more or less prescribed by the state of the subject - as in other sciences-I should have thought a mixture of Tinbergen and pure theory was the right answer." (801-805)

Keynes' response to this letter of Harrod has been available for some time in Keynes's published letters, but is nonetheless quite startling:

"My point against Tinbergen is a different one. In chemistry and physics and other natural sciences the object of experiments is to fill in the actual values of the various quantities and factors appearing in an equation or a formula; and the work when done is once and for all. In economics that is not the case, and to convert a model into quantitative formula is to destroy its usefulness as an instrument of thought. Tinbergen endeavors to work out the variable quantities in a particular case, or perhaps in the average of several particular cases, and he then suggest that the quantitative formula so obtained has general validity.... All the statisticians 
tend that way.... The pseudo-analogy with the physical sciences

leads directly counter to the habit of mind which is most important for an economist proper to acquire.” (803-805)

Herein, of course, is a problem. It's uncomfortable for economists to have to say it, but Keynes was essentially clueless about the natural sciences. His view of them reflected a Tripos education in mathematics which stopped around 1900. That Keynes thought that quantitative work in the sciences was a matter of filling in correct values for coefficients and equations strikes a modern reader as bizarre. More importantly of course, that notion was out of touch with the time in which he himself was living. For this was the decade of the stabilization of quantum mechanics, of the development of nuclear physics, of the mathematics of algorithmics, and so much more. The idea in the 1930s that experimental scientists "filled in the values" of theoretical coefficients demonstrates a lack of familiarity with 1930s natural sciences. Of course for a historian, one can clearly contextualize these kinds of thought-positions by locating them in a particular time and place of the speakers' development both intellectually and socially. Recall that in 1938, Keynes was 55 years old, not an age in which new ways of thinking entirely different from established ways, in fields far removed from one's own, in fact in fields for which one has a slight repugnance, are not common. That this kind of obiter dicta by Keynes with respect to Tinbergen should be taken as the founding text of a modern Cambridge tradition of seeing that Marshall was concerned about mathematics taking over economics, ending up with Tony Lawson's critical realist objections, through related ontological theoretical work, about the problematic relation of mathematics and economic reality, is more than an historical error, it is nonsense, at least historical nonsense whether the philosophers believe so or not. I want to 
stress, however, that this exchange of letters between Harrod and Keynes concerning Tinbergen has played a quite important role in the development of a reconstructed Cambridge, or, as I prefer to call it, a mythical Cambridge. It is embarrassing for a modern economist to read Keynes's adamant follow-up on 23 August 1938: "I have not escaped having to consider Tinbergen's stuff . . . so far as I can understand the matter, my present belief is that it is almost pure hocus. But it is all so obscure that I cannot confidently assert this." (838-839).

In a similar vein, and at roughly the same time, we find a letter from Harrod to Marschak dated 6 August 1938 (page 811-812). "I hoped that as I wrote this out, means of giving empirical check to the theory could suggest themselves. I fear that this has not been the case. The relations which can be empirically measured even by the most refined methods are so crude by comparison with the theory of this sort, and that despite the fact that I have presented it in an extremely simple form, and by reasoning in which there is only one step. But I confess that I haven't really given my mind on the verification aspect. If you can do so, without unduly encumbering your time and exhausting your energy, I should be very grateful if you could read through this and consider it from the point-of-view of verification. We might then be in a position to talk over possibilities." (This was the cover letter to Harrod's essay in Dynamic Theory of 1939 reprinted in volume 3 here as Essay 19.)

Of more interest though is Marschak's response to Harrod's essay in Dynamic Theory, (page 844-849, dated late August or early September 1938) In this letter, Marschak attempts to construct the formal mathematical framework of Harrod's theory. He develops various kinds of differential equations modeling growth, together with some truncations of the smooth paths at 
various ceilings associated with the natural rate of growth. That is, we have a general dynamic model with various kinds of floors and ceilings, which changed the smooth dynamics quite profoundly. Tinbergen of course had argued that this way of thinking involved a periodization of the dynamics, perhaps as mixed differential-difference equations. In any event, that is not the path that Marschak took in reconstructing the formal model. Harrod on 7 September 1938 replied to Marschak (page 859-861): "You asked me the leading question whether my theory that there are centrifugal forces on each side of the equilibrium (warranted rate) is based on some empirical view as to entrepreneurs' probable reactions. I do not think so. On the other hand there must be some empirical basis for my theory. This may be summarized in two propositions. 1. The volume of saving supplied depends mainly on the size of income. 2. A considerable part of the demand for saving depends on the rate of growth. There, I think, empiricism ends and deduction begins. It seems to me that we have here an opportunity of doing some important deduction from a few very broad empirical generalizations."

Keynes, meanwhile, was shoveling dirt on Tinbergen again as he wrote to Harrod on 13 September 1938 (page 862): "If Tinbergen was a private research student, he would deserve every encouragement. It is certainly worth his while pursuing all of this. But I think it very dangerous for a collection of responsible economists to give it any sort of imprimatur in its present stage."

I have not touched on a host of other historical matters made accessible though Besomi's project - the development of Oxford economics, the activities of economists in public discussion of economic affairs in the interwar years, economists' activities in the political life of England in 
those years, and so on. Nearly any historian of economics will find a great deal in these volumes with which to engage. But as scholars, we will delight as well in the editor's careful work. Suffice it to say that the Harrod letters will be used by many scholars, in different fields, for a long time. The Besomi volumes' purchase is mandatory for all libraries interested in economics, the history of economics, and twentieth century history.

\section{References}

Besomi, D. (1999). The Making of Harrod's Dynamics. New York, St. Martin's Press.

Davis, J. Ronnie. (1971) The new economics and the old economists. Ames, Iowa State University Press.

Howson, Susan. (1977) The Economic Advisory Council, 1930-1939: a study in economic advice during depression and recovery. Cambridge, [Eng.]; New York: Cambridge University Press.

Hutchison, T. W. (1968) Economics and economic policy in Britain, 1946-1966: some aspects of their interrelations. London, Allen \& Unwin, 1968.

Jolink, A. (1995). "Anecdotal Myths": Tinbergen's influence on Harrod's Growth Theory"." European Journal of the History of Economic Thought 2(2).

Lawson, T. (2004). "The (Confused) State of Equilibrium Analysis in Modern Economics: an Explanation." Journal of Post Keynesian Economics. 
Nelson, R. H. (2003). "Review of Michael Bernstein's A Perilous Progress." The Independent Review 8(2).

Weintraub, E. R. (2005). "Autobiographical Memory and the Historiography of Economics." Journal of the History of Economic Thought 27(2). 
Correspondence may be addressed to E. Roy Weintraub, Department of Economics, Duke University, Durham, North Carolina USA 27708-0097; e-mail: erw@duke.edu.

${ }^{1}$ This is a review essay of Daniele Besomi, Ed. (2003). The Collected Interwar Papers and Correspondence of Roy Harrod. Cheltenham UK and Northampton MA, Edward Elgar.

${ }^{2}$ Parenthetical numbers refer to the page in the three volumes where the material appears. Since the three volumes are paginated as one volume, no specific volume reference is noted. 